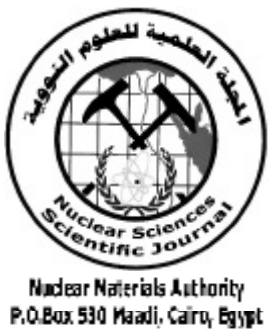

ISSN 2314-5609

Nuclear Sciences Scientific Journal

vol. 3 , p $123-138$

2014

\title{
RADIOACTIVITY AND GENETIC RELATION BETWEEN THE MONZOGRANITES AND THE ENCLOSED PEGMATITES IN DAHAB AREA, SOUTHEASTERN SINAI, EGYPT
}

\author{
ABDEL MOEZ A. SADEK; ABDEL HADI A. ABBAS and MOHAMED O.EL HUSSEINY \\ Nuclear Materials Authority, P.O. 530, Maadi, Cairo, Egypt
}

\begin{abstract}
The study area lies at the southeastern part of Sinai Peninsula along the western bank of Gulf of Aqaba occupying the extreme southern part of the Arabian- Nubian Shield. Dahab area is mainly covered by volcanic rocks, younger gabbros, younger granites and pegmatites. The pegmatite bodies of the study area are abundant, hosted in monzogranites and distinguished into zoned and unzoned types. They are found as lenticular pocket and vein-like bodies. Some of these pegmatite bodies have abnormal radioactivity. Radionuclide measurements of younger granites show that their equivalent uranium content $(\mathrm{eU})$ ranges between $6 \mathrm{ppm}$ and $11 \mathrm{ppm}$, while their equivalent thorium (eTh) varies from $13 \mathrm{ppm}$ to $26 \mathrm{ppm}$. The average contents of $U$ and $\mathrm{Th}$ of the anomalous pegmatites are $88.6 \mathrm{ppm}$ and $107.9 \mathrm{ppm}$, respectively indicating their uraniferous nature.

Geochemically, Both monzogranites and pegmatites have high K-calc alkaline characters, metaluminous and peralkaline natures, intruded in withinplate condition, derived from magma of crustal materials source of moderate fractionation.

The Mineralogical investigations of anomalous pegmatites revealed the presence of secondary uranium mineral (autunite), in addition to thorite, uranothorite, zircon, monazite and columbite. Primary and secondary radioactive mineralizations indicating that the mineralization is not only magmatic, but also post-magmatic.

\section{NTRODUCTION}

The Egyptian younger granites are considered as the final stage of plutonism ceased at the end of the Precambrian at $550 \mathrm{Ma}$ (El Shazly et al., 1980) to $417 \mathrm{Ma}$ (Stern and Hedge, 1985). They were intruded towards the closing stage of cratonization (Collins et al., 1985; Nardi and Bonin, 1991). These granites are emplaced as small ovoid shallow level intrusions, widely distributed and mark the beginning of the crustal stabilization of the Arabian- Nubian Shield (Harris, 1985; Bowden, 1985). El Badawi (1988) considered that the younger granites of South Dahab area belong

to the Late Proterozoic and the beginning of the Early Paleozoic.

The studied area lies at the southeastern part of Sinai Peninsula along the western bank of the Gulf of Aqaba (Fig.1). It occupies the extreme southern part of the Arabian- Nubian Shield. The area has been studied by many authors as Beyth et al., 1975; Eyal et al., 1989; Katta, 1989; Itamar, 1989; El Masry, 1989, Abu El Liel et al., 1990; El Sayed, 1993; El Aassy et al., 1997; and Khalaf, 2002. Most of these studies clarified that the area is mainly composed of acidic extrusive rocks (Feirani volcanic rocks) and intrusive epizonal granitic rocks (older and younger granites).
\end{abstract}




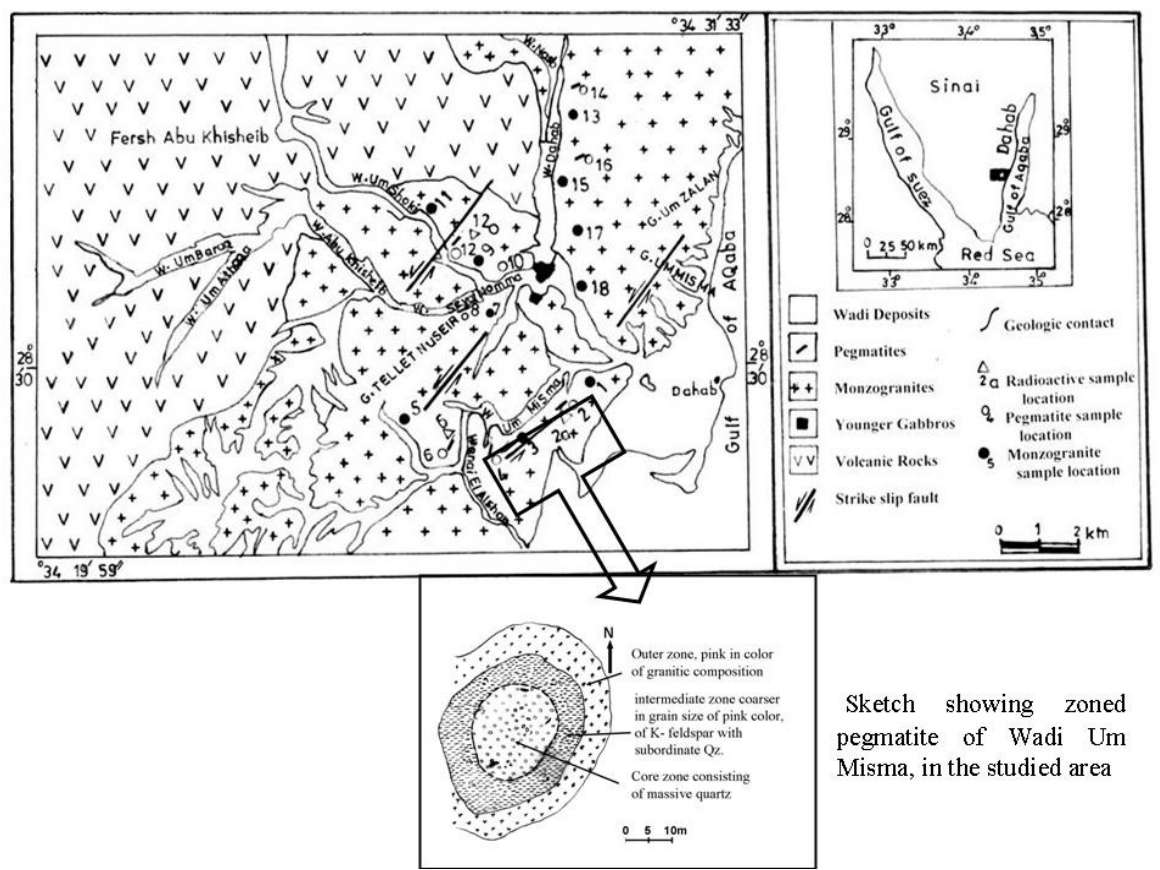

Fig.1: Geologic map of the studied area (Modified after El Sayed, 1993)

The present study is concerned with the petrography, geochemistry and radioactivity of the monzogranites and associated pegmatites. It aims to understand the genetic relationship between these two rock types, and deals with the mineralogy of anomalous pegmatites.

\section{SAMPLING AND METHODOLOGY}

Eighteen representative samples $(10$ from monzogranites and 8 from pegmatites) are prepared for microscopic examinations. These samples are also chemically analysed by wet chemical methods after Shapiro and Brannock (1962) for major oxides and X- ray fluorescence for some trace elements. Radiometric elements are determined using multichannel analyzer of $\gamma$ - ray detector (Gamma sepectrometer technique). Heavy liquid and magnetic separations as well as X-ray diffraction and Environmental Electron Microscope (ESEM) were done to identify the minerals responsible for the radioactivity in anomalous pegmatites. All analyses were achieved in the
Laboratories of the Nuclear Materials Authority (NMA) of Egypt.

\section{GEOLOGIC SETTING}

The study area is located between Lat. $28^{\circ} 27^{\prime}$ and $28^{\circ} 35^{\prime} \mathrm{N}$ and Long. $34^{\circ} 19^{\prime} 59^{\prime \prime}$ and $34^{\circ} 31^{\prime} 33^{\prime \prime} \mathrm{E}$ (Fig.1). The area is covered by volcanic rocks, younger gabbros, younger granites and pegmatites.

\section{Volcanic Rocks}

The volcanic rocks occupy the western part of the mapped area. These rocks are characterized by their high relief, rhyodacite to rhyolite in composition, and range in color from grey, dark grey to pink color. Abu El Liel et al. (1990) concluded that these volcanic rocks were erupted later than the Dokhan volcanics cutting phase II younger granites and are cut by phase III younger granites. On the other hand, El Sayed, 1993 stated that these rocks correspond to the Dokhan volcanics where they are intruded by the monzogranites. 


\section{Younger Gabbros}

The Younger gabbros occur as small intrusions at the intersection between Wadi Seyal Nomma and Wadi Dahab (Fig.1). They are intruded by the monzogranites with sharp intrusive contact. These rocks are fresh, medium to coarse- grained and dark grey in color.

\section{Younger Granites}

These rocks are mainly monzogranites covering the eastern part of the mapped area. They are highly weathered and cut by swarms of acidic, intermediate and basic dykes. They are coarse- grained, pink in color and host large number of pegmatite bodies.

\section{Pegmatites}

The pegmatite bodies of the study area are abundant, hosted in monzogranites and distinguished into zoned and unzoned types. Some of these pegmatite bodies are characterized by high radioactivity (anomalous pegmatites).

The zoned pegmatites are lenticular in shape, and occur at wadi Um Misma, Um Shoki and Seyal Nomma. They mainly consist of: a)- border (wall) zone, coarse-grained, pink in color ranging from $30 \mathrm{~cm}$ to $1 \mathrm{~m}$ in width and of granitic composition, b)- intermediate zone, it is coarser in grain size and larger in width ranging from $50 \mathrm{~cm}$ to $2 \mathrm{~m}$, pink in color and mainly consists of K- feldspar with subordinate quartz and c)- core zone consists of massive quartz ranging in diameter from $1 \mathrm{~m}$ to $4 \mathrm{~m}$ (Fig. 1). Some pegmatite bodies have high radiometric measurements (Wadi Um Misma).

The unzoned pegmatites are very coarsegrained, pink in color and occur as pockets and veins composed of $\mathrm{K}$-feldspar, quartz and biotite, occurring at wadis Um Misma, Qnai El Atshan and Um Shoki. Some pockets have dimensions reaching up to $(5 \times 25 \mathrm{~m})$ and attain high radioactive measurements (Wadis Qnai El Atshan and Um Shoki).

\section{PETROGRAPHY}

Plotting the studied samples on the Q-A-P of Streckeisn diagram (1976) for classification of igneous rocks clarified that most of the pegmatitic samples fall in the field of alkalifeldspar granite except three samples which fall in the field of syenogranite (close to the field of alkali-feldspar). On the other hand, the granitic samples are plotted in monzogranite field except 3 samples related to the field of syenogranite (Fig. 2).

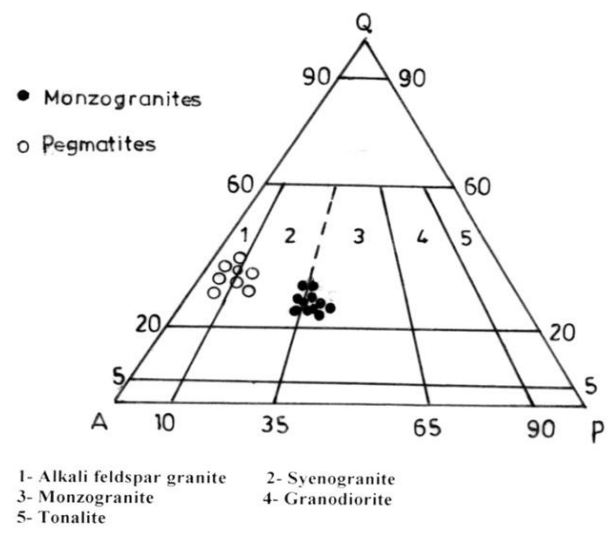

Fig.2: QAP diagram of monzogranites $(\bullet)$ and pegmatites $(\circ)$ of the studied area ,according to Streckeisn, 1976

\section{Monzogranite}

Petrographically these rocks are composed essentially of quartz, K-feldspar, plagioclase and biotite with subordinate amount of hornblende. Zircon, apatite, muscovite and opaques are accessory minerals. Graphic and poikilitic textures are common in these rocks.

\section{Quartz}

It occurs as subhedral crystals with moderate undulose extinction. Some fine crystals are poikilitically enclosed in large $\mathrm{K}$-feldspar crystals.

\section{K-feldspars}

They are mainly orthoclase perthite and microcline perthite. Orthoclase perthite crystals are found as anhedral to subhedral pris- 
matic crystals, medium- to coarse-grained and showing string and patchy types. Microcline perthite exhibits cross-hatching twinning and is corroded by quartz (Fig. 3).

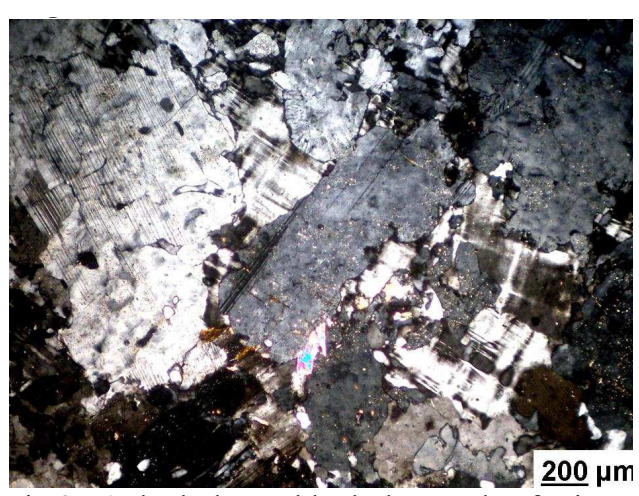

Fig.3 : Anhedral to subhedral crystals of microcline perthite, Dahab monzogranite,XPL

\section{Plagioclase (An5- 12)}

It is found as subhedral to anhedral prismatic crystals of medium- to coarse- grain size. These crystals have cloudy and dusty appearance exhibiting albitic lamellar twinning. Some plagioclase crystals show selective alteration in the core being partially sericitized; and corroded by perthite and quartz (Fig. 4).

\section{Mafic minerals}

They are present in subordinate amounts represented by biotite, secondary muscovite and few amount of hornblende.

Biotite occurs as small flakes of dark brownish color, pleochroic, chloritized, and muscovitized. They are mainly mottled with iron oxides and associated with some accessory minerals.

Muscovite is less common than biotite.

Hornblende occurs as deep green crystals, pleochroic and corroded by quartz, perthite and plagioclase, intimately associated with biotite (Fig. 5).

Accessory minerals are mainly represented by zircon, apatite and fluorite. Small aggregates of euhedral to subhedral prismatic crys- tals of zircon, usually metamict, embedded in quartz and feldspars are surrounded by iron oxides (Fig. 6).

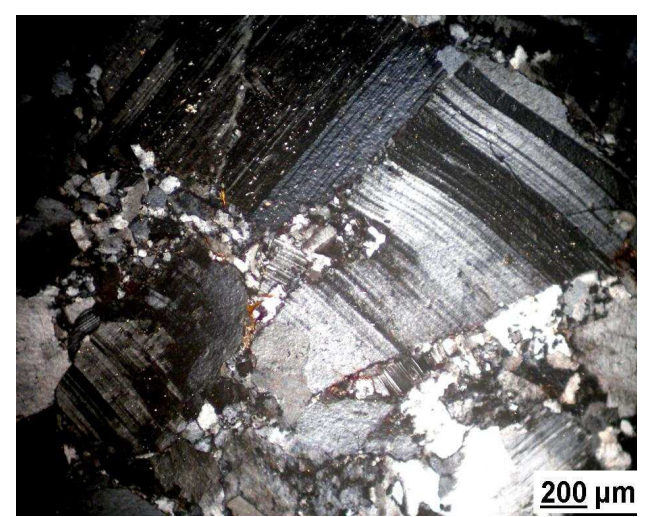

Fig.4: Subhedral to anhedral prismatic crystals of plagioclase corroded by perthite of Dahab monzogranite, XPL

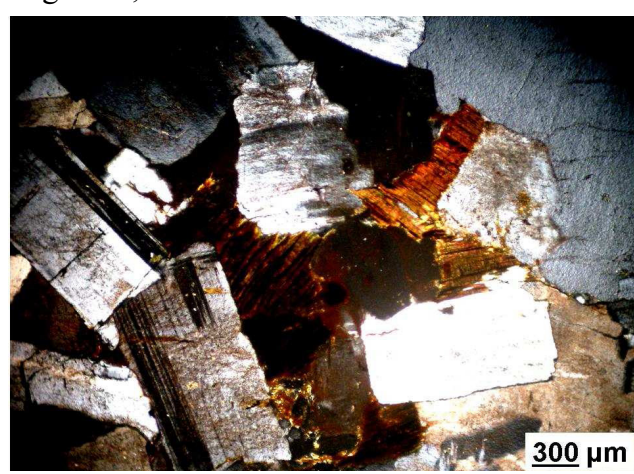

Fig.5: Biotite flakes associating plagioclase, XPL

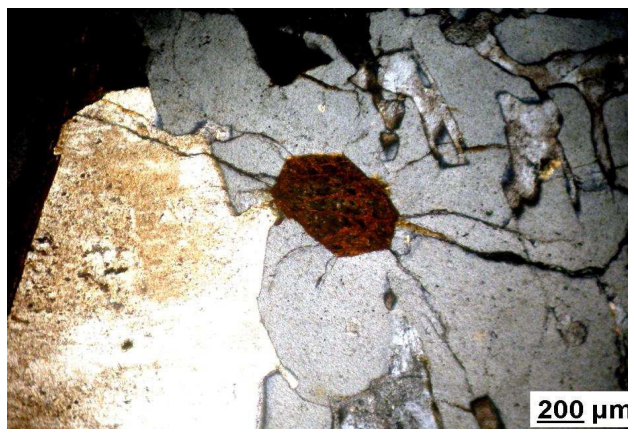

Fig.6:Metamict zircon embedded in plagioclase, XPL 


\section{Pegmatites}

They consist of K-feldspar, quartz with subordinate plagioclase, muscovite and biotite; opaques and zircon are found as accessory minerals. Quartz is commonly intergrown with K-feldspar developing graphic texture (Fig. 7). K-feldspar is the common mineral constituent occurring as orthoclase microperthite. Plagioclase occurs as albite (An5 -10) euhedral crystals with albite twinning. Partial alteration to sericite is observed especially in the cores (Fig. 8). Muscovite exists either as primary euhedral flakes and/or secondary interstitial crystals associated with K-feldspar. Biotite is euhedral elongated flaky crystals slightly altered to chlorite.Zircon occurs as prismatic crystals, some crystals are metamicted, fractured and damaged due to the effect of radiation.Opaques are commonly associated with biotite flakes.

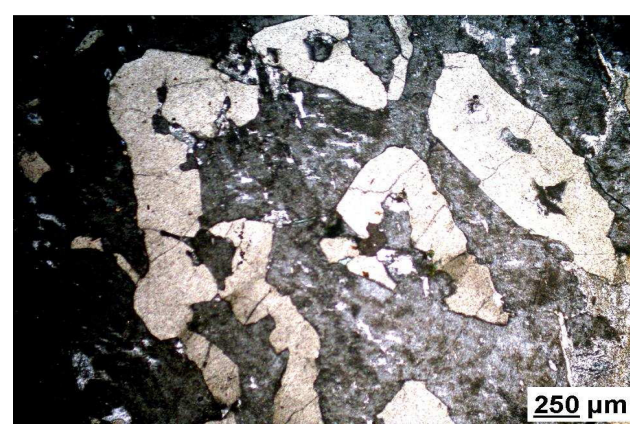

Fig.7: Quartz is commonly intergrown with perthite developing graphic texture in Um Shoki pegmatite,XPL

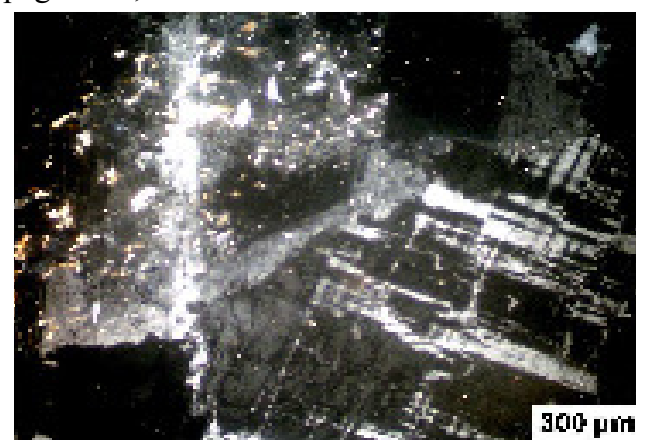

Fig.8: Euhedral crystals of plagioclase showing partial alteration to sericite in Um Shoki pegmatite,XPL

\section{GEOCHEMISTRY}

Eighteen samples (10 samples from the monzogranites and 8 samples from the hosted pegmatites) were chemically analyzed for major oxides (wt\%) by wet chemical methods Shapiro and Brannock (1962) and El-Reedy (1984), while the trace elements were determined in (ppm) using XRF technique in the Nuclear materials Authority labs. The results are shown in Tables (1\&2).

\section{Chemical Characteristics and Type of Granites}

Chemical variations within rocks of one or more magma series of different regions may be visualized by applying Harker diagrams(1909). The major element variations relative to $\mathrm{SiO}_{2}$ are used as an index of differentiation for the studied rocks. The Harker variation diagrams exhibit normal relationships reflecting positive correlation between $\mathrm{SiO}_{2}$ vs. $\mathrm{K}_{2} \mathrm{O}, \mathrm{Na}$, $\mathrm{Rb}$ and $\mathrm{Nb}$ (Figs.9-12) while show negative relationships between $\mathrm{Al}_{2} \mathrm{O}_{3}, \mathrm{CaO}, \mathrm{Sr}$ and $\mathrm{Ba}$ (Figs.13-16). The linear trends on Harker variation diagrams may indicate that the study monzogranites are probably the precursor from which the pegmatites have been derived by fractional crystallization.

Table 1: Major oxides (wt $\%$ ), trace elements (ppm) and some geochemical ratios of the studied monzogranite

\begin{tabular}{|c|c|c|c|c|c|c|c|c|}
\hline${ }_{\text {Oxides }}^{\text {Sp.No. }}$ & 2 & 4 & 6 & 8 & 10 & 12 & 14 & 16 \\
\hline $\mathbf{S i O}_{2}$ & 73.7 & 74.1 & 72.8 & 72.3 & 73.9 & 73.2 & 74.3 & 72.6 \\
\hline $\mathrm{TiO}_{2}$ & 0.17 & 0.32 & 0.21 & 0.67 & 0.90 & 0.32 & 0.21 & 0.09 \\
\hline $\mathrm{Al}_{2} \mathrm{O}_{3}$ & 12.56 & 12.76 & 12.13 & 12.68 & 12.02 & 12.82 & 12.34 & 12.36 \\
\hline $\mathrm{Fe}_{2} \mathrm{O}_{3}$ & 1.33 & 0.3 & 1.09 & 1.35 & 0.83 & 1.07 & 1.06 & 1.31 \\
\hline $\mathrm{FeO}$ & 0.22 & 0.52 & 0.3 & 0.47 & 0.21 & 0.86 & 0.13 & 1.72 \\
\hline MnO & 0.09 & 0.18 & 0.27 & 0.84 & 0.64 & 0.01 & 0.81 & 0.28 \\
\hline MgO & 0.13 & 0.07 & 0.06 & 0.13 & 0.35 & 0.07 & 0.07 & 0.02 \\
\hline $\mathrm{CaO}$ & 0.94 & 0.86 & 0.98 & 1.20 & 0.85 & 1.02 & 0.83 & 1.10 \\
\hline $\mathrm{Na}_{2} \mathrm{O}$ & 4.36 & 4.17 & 4.61 & 4.10 & 4.20 & 3.98 & 4.13 & 4.18 \\
\hline $\mathrm{K}_{2} \mathrm{O}$ & 4.7 & 5.36 & 4.72 & 5.37 & 5.03 & 5.16 & 5.07 & 4.86 \\
\hline $\mathrm{P}_{2} \mathrm{O}_{5}$ & 0.23 & 0.32 & 0.63 & 0.43 & 0.23 & 0.36 & 0.41 & 0.67 \\
\hline L.O.I & 0.16 & 0.91 & 1.52 & 0.70 & 0.57 & 0.79 & 1.30 & 1.56 \\
\hline Total & 98.59 & 99.87 & 99.32 & 100.24 & 99.73 & 99.66 & 100.66 & 100.75 \\
\hline \multicolumn{9}{|c|}{ Trace elements (ppm) } \\
\hline $\mathrm{Cu}$ & 13 & 20 & 18 & 18 & 16 & 20 & 30 & 15 \\
\hline $\mathbf{P b}$ & 15 & 12 & 13 & 10 & 15 & 18 & 14 & 12 \\
\hline $\mathbf{R b}$ & 210 & 206 & 200 & 227 & 206 & 213 & 210 & 200 \\
\hline Ba & 60 & 100 & 76 & 100 & 85 & 86 & 103 & 100 \\
\hline Sr & 78 & 83 & 60 & 97 & 101 & 72 & 82 & 67 \\
\hline $\mathbf{N b}$ & 25 & 30 & 20 & 26 & 20 & 28 & 22 & 35 \\
\hline $\mathbf{Z r}$ & 300 & 253 & 210 & 350 & 263 & 316 & 275 & 246 \\
\hline $\mathbf{Y}$ & 80 & 75 & 73 & 67 & 60 & 65 & 78 & 80 \\
\hline Ga & 20 & 18 & 20 & 22 & 20 & 13 & 10 & 10 \\
\hline \multicolumn{9}{|c|}{ Geochemical ratios } \\
\hline $\mathrm{Na}_{2} \mathrm{O} / \mathrm{K}_{2} \mathrm{O}$ & 0.93 & 0.78 & 0.98 & 0.76 & 0.83 & 0.77 & 0.81 & 0.86 \\
\hline $\mathbf{B a} / \mathbf{R b}$ & 0.29 & 0.49 & 0.38 & 0.44 & 0.41 & 0.40 & 0.49 & 0.50 \\
\hline $\mathbf{R b} / \mathbf{S r}$ & 2.69 & 2.48 & 3.33 & 2.34 & 2.04 & 2.96 & 2.56 & 2.99 \\
\hline $\mathbf{Y} / \mathbf{N b}$ & 3.2 & 2.5 & 3.65 & 2.58 & 3.0 & 2.32 & 3.55 & 2.29 \\
\hline
\end{tabular}


Table 2: Major oxides (wt $\%)$, trace elements (ppm) and some geochemical ratios of the studied pegmatites

\begin{tabular}{|c|c|c|c|c|c|c|c|c|}
\hline${ }_{\text {Oxides }}^{\text {Sp.No. }}$ & 2 & 4 & 6 & 8 & 10 & 12 & 14 & 16 \\
\hline$\overline{\mathrm{SiO}_{2}}$ & 73.7 & 74.1 & 72.8 & 72.3 & 73.9 & 73.2 & 74.3 & 72.6 \\
\hline $\mathrm{O}_{2}$ & 0.17 & 0.32 & 0.21 & 0.67 & 0.90 & 0.32 & 0.21 & 0.09 \\
\hline $\mathrm{Al}_{2} \mathrm{O}_{3}$ & 12.56 & 12.76 & 12.13 & 12.68 & 12.02 & 12.82 & 12.34 & 12.36 \\
\hline $\mathrm{Fe}_{2} \mathrm{O}_{3}$ & 1.33 & 0.3 & 1.09 & 1.35 & 0.83 & 1.07 & 1.06 & 1.31 \\
\hline 0 & 0.22 & 0.52 & 0.3 & 0.47 & 0.21 & 0.86 & 0.13 & 1.72 \\
\hline MnO & 0.09 & 0.18 & 0.27 & 0.84 & 0.64 & 0.01 & 0.81 & 0.28 \\
\hline MgO & 0.13 & 0.07 & 0.06 & 0.13 & 0.35 & 0.07 & 0.07 & 0.02 \\
\hline $\mathrm{CaO}$ & 0.94 & 0.86 & 0.98 & 1.20 & 0.85 & 1.02 & 83 & 1.10 \\
\hline $\mathrm{Na}_{2} \mathrm{O}$ & 4.36 & 4.17 & 4.61 & 4.10 & 4.20 & 3.98 & 13 & 4.18 \\
\hline $\mathrm{K}_{2} \mathrm{O}$ & 4.7 & 5.36 & 4.72 & 37 & 5.03 & 5.16 & 5.07 & 4.86 \\
\hline $\mathrm{P}_{2} \mathrm{O}$ & 0.23 & 0.32 & 0.63 & 0.43 & 0.23 & 0.36 & 0. & 0.67 \\
\hline L.O.I & 0.16 & 0.91 & 1.52 & 0.70 & 0.57 & 0.79 & 1.30 & 1.56 \\
\hline Total & 98.59 & 99.87 & 99.32 & 100.24 & 99.73 & 99.66 & 100.66 & 100.75 \\
\hline \multicolumn{9}{|c|}{ Trace elements (ppm) } \\
\hline $\mathrm{Cu}$ & 13 & 20 & 18 & 18 & 16 & 20 & 3 & 15 \\
\hline $\mathrm{Pb}$ & 15 & 12 & 13 & 10 & 15 & 18 & 14 & 12 \\
\hline $\mathbf{R b}$ & 210 & 206 & 200 & 227 & 206 & 213 & 10 & 200 \\
\hline B & 60 & 100 & 76 & 100 & 85 & 86 & 10 & 100 \\
\hline $\mathrm{Sr}$ & 78 & 83 & 60 & 97 & 101 & 72 & 8 & 67 \\
\hline $\mathrm{Nb}$ & 25 & 30 & 20 & 26 & 20 & 28 & 22 & 35 \\
\hline $\mathrm{Zr}$ & 300 & 253 & 210 & 350 & 263 & 316 & 275 & 246 \\
\hline Y & 80 & 75 & 73 & 67 & 60 & 65 & 78 & 80 \\
\hline Ga & 20 & 18 & 20 & 22 & 20 & 13 & 10 & 10 \\
\hline \multicolumn{9}{|c|}{ ical ratios } \\
\hline $\mathrm{Na}_{2} \mathbf{O} /$ & 0.93 & 0.78 & 0.98 & 0.76 & 0.83 & 0.77 & 81 & 0.86 \\
\hline $\mathbf{B a} / \mathbf{R}$ & 0.29 & 0.49 & 0.38 & 0.44 & 0.41 & 0.40 & 49 & 0.50 \\
\hline & 2.69 & 2.48 & 3.33 & 2.34 & 2.04 & 2.9 & & 2.99 \\
\hline $\mathrm{Y} / \mathrm{Nb}$ & 3.2 & 2.5 & 3.65 & 2.58 & 3.0 & 2.32 & 3.55 & 2.2 \\
\hline
\end{tabular}

The R1-R2 discrimination diagram of De La Roche et al.(1980) shows that the samples of the investigated granites fall in the monzogranite field, while the studied samples of pegmatites occupy syenogranite and alkali granite fields nearly conform with the petrographical studies (Fig.17). The $\mathrm{K}_{2} \mathrm{O}$ versus $\mathrm{SiO}$ diagram of Peccerillo and Taylor (1976) exhibits high K-calc- alkaline and shoshonitic affinities of the study rocks (monzogranites and associated pegmatites), (Fig.18).

\section{Magma Type and Tectonic Setting}

Cox et al. (1979) stated that the granites originating from the crust have $\mathrm{Na}_{2} \mathrm{O} / \mathrm{K}_{2} \mathrm{O}$ ratio less than 1. Most of the studied samples of the monzogranites and associated pegmatites are characterized by $\mathrm{Na}_{2} \mathrm{O} / \mathrm{K}_{2} \mathrm{O}$ ratios less than 1 suggesting that these rocks originated from magma of crustal materials. some samples $(3,5,13$ and15) of the monzogranitic rocks slightly deviate from this value $(>1)$ Table(1) referring to a probable sodic metasomatism.

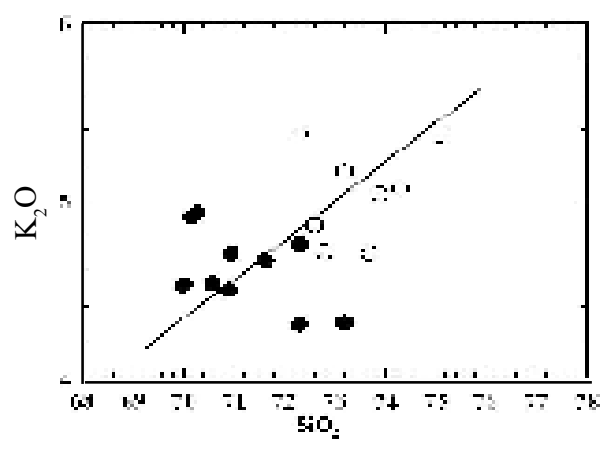

Fig.9: Harker variation diagrams $\mathrm{SiO}_{2} \mathrm{Vs}$. $\mathrm{K}_{2} \mathrm{O}$ of monzogranites and pegmatites. Symbols as in Fig.2.

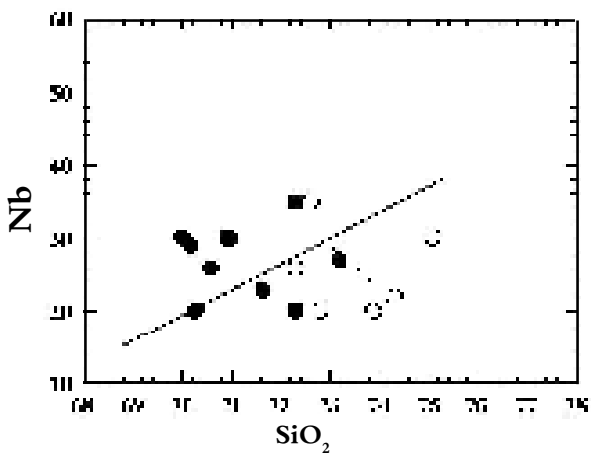

Fig. 10: Harker variation diagrams $\mathrm{SiO}_{2} \mathrm{Vs}$. $\mathrm{Nb}$ of monzogranites and pegmatites. Symbols as in Fig.2.

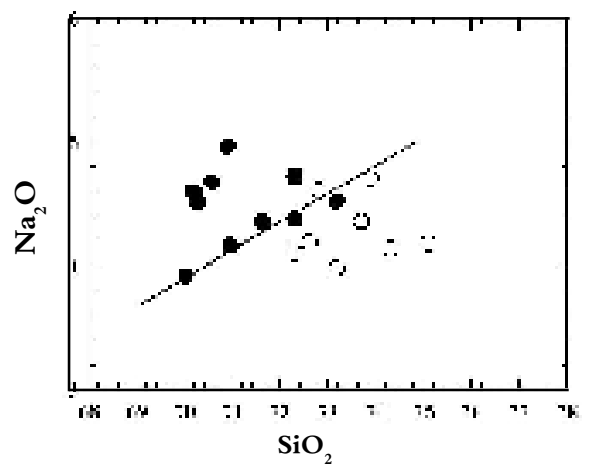

Fig. 11: Harker variation diagrams $\mathrm{SiO}_{2} \mathrm{Vs}$. $\mathrm{Na}_{2} \mathrm{O}$ of monzogranites and pegmatites. Symbols as in Fig.2. 


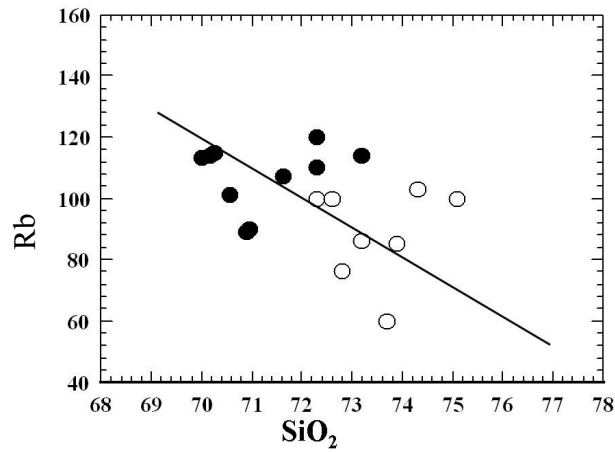

Fig.12: Harker variation diagrams $\mathrm{SiO}_{2} \mathrm{Vs}$. $\mathrm{Rb}$ of monzogranites and pegmatites. Symbols as in Fig.2

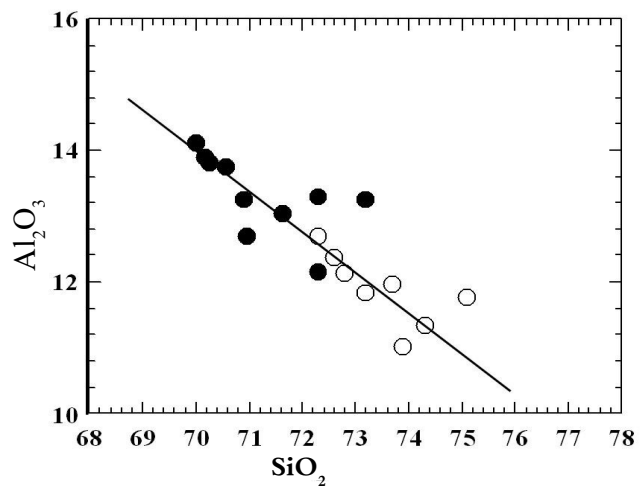

Fig.13: Harker variation diagrams $\mathrm{SiO}_{2} \mathrm{Vs} . \mathrm{Al}_{2} \mathrm{O}_{3}$ of monzogranites and pegmatites. Symbols as in Fig.2.

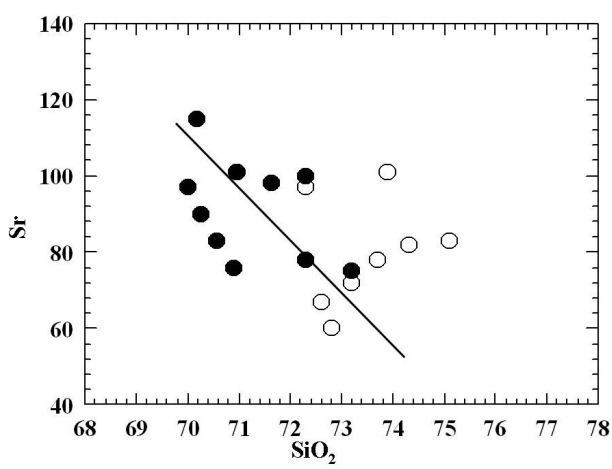

Fig. 14: Harker variation diagrams $\mathrm{SiO}_{2} \mathrm{Vs}$. $\mathrm{Sr}$ of monzogranites and pegmatites. Symbols as in Fig. 2

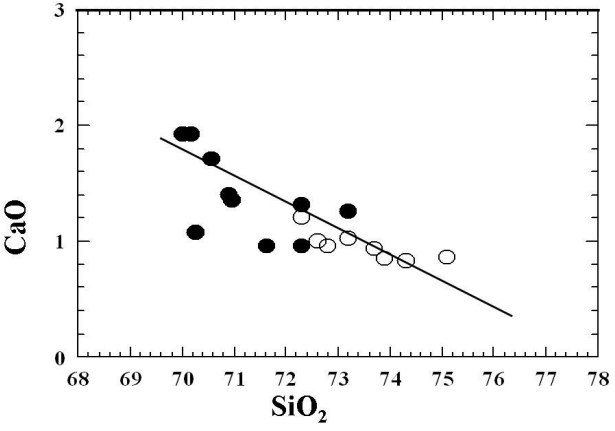

Fig.15: Harker variation diagrams $\mathrm{SiO}_{2} \mathrm{Vs}$. $\mathrm{CaO}$ of monzogranites and pegmatites. Symbols as in Fig.2

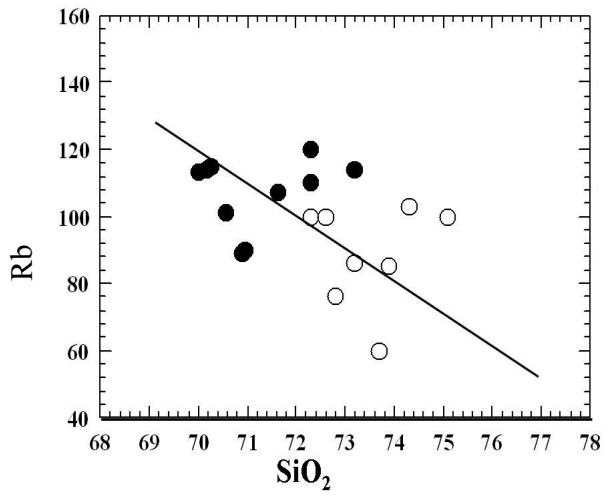

Fig.16: Harker variation diagrams $\mathrm{SiO}_{2}$ Vs. $\mathrm{Ba}$ of monzogranites and pegmatites. Symbols as in Fig.2.

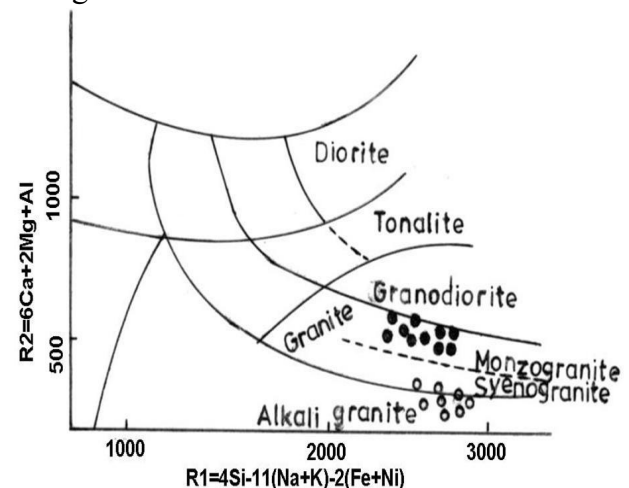

Fig.17: R1-R2 discrimination diagram of the monzogranite and pegmatite according to De La Roche et al.,1980. Symbols as in Fig.2 


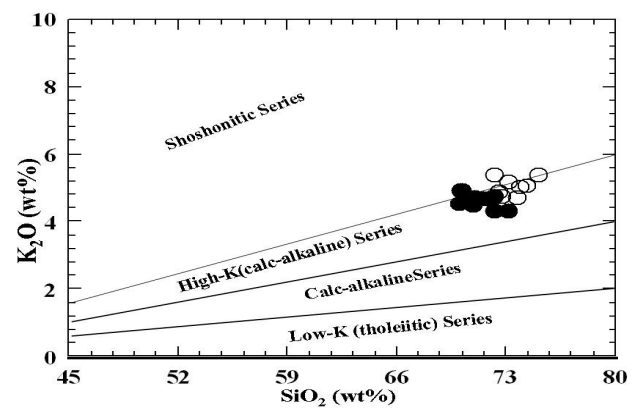

Fig. 18: $\mathrm{K}_{\mathrm{O}} \mathrm{O} \mathrm{Vs} \mathrm{SiO}_{2}$ diagram according to Peccerillo and Taylor,1976. Symbols as in Fig.2

According to $\mathrm{A} / \mathrm{CNK}$ versus $\mathrm{A} / \mathrm{NK}$ binary diagram of Shand's index (1950), the majority of the studied monzogranites are metaluminous in nature, while the pegmatite samples exhibit peralkaline character (Fig.19).

The $\mathrm{Y}$ versus $\mathrm{Nb}$ diagram of Pearce et al. (1984) indicates that both the monzogranites and the pegmatites were emplaced in withinplate environment (Fig.20). The $\mathrm{K}_{2} \mathrm{O}$ versus Ba diagram of Mason (1966) reflect the crustal materials source of both the studying monzogranite and pegmatite rocks (Fig.21).

The $\mathrm{Y} / \mathrm{Nb}$ ratio in continental crust is 2 or more (Taylor and McLennan, 1985). This ratio ranges from 2.0 to 3.0 for the monzogranites and from 2.3 to 3.65 in the investigated pegmatites, which is usually greater than 2 reflecting and supporting the probability of their crustal origin. Eby (1990) classified the A-type granites into two group depending on the $\mathrm{Y} / \mathrm{Nb}$ ratios. He suggested that the first group with $(\mathrm{Y} / \mathrm{Nb}<1.2)$ was differentiated from basaltic magma directly derived from oceanic island basalts like mantle source. While the second group $(\mathrm{Y} / \mathrm{Nb}=1.2-7)$ exhibits a complex petrogenetic history and may have a significant mantle component, or may be totally of crustal origin. According to this classification, the examined monzogranites and associated pegmatites belong to the second group suggesting crustal derivation.

Bucanan (1982) suggested that the high

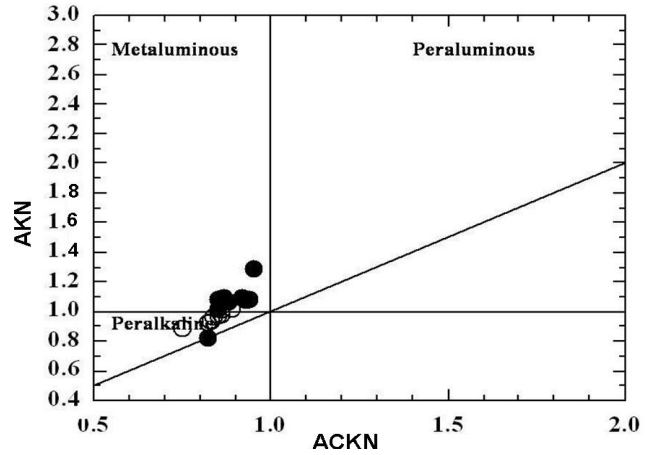

Fig.19: Shand's index diagram of the monzogranite and pegmatites. According to Clarke, 1981. Symbols as in Fig. 2

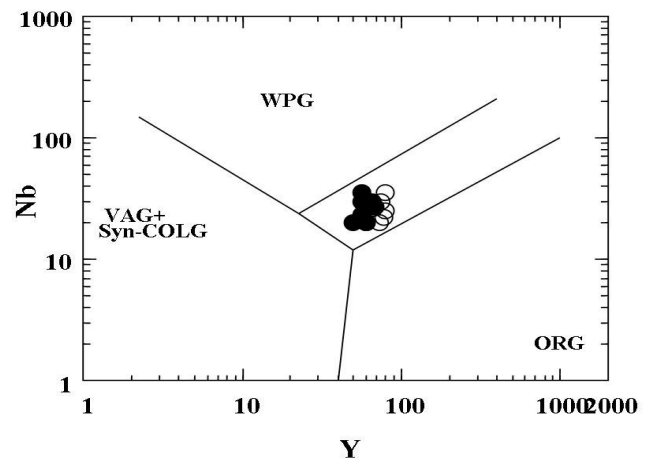

Fig.20: $\mathrm{Nb}$ vs.Y discrimination diagram of the monzogranite and pegmatites according to Pearce et al., 1984. Symbols as in Fig.2

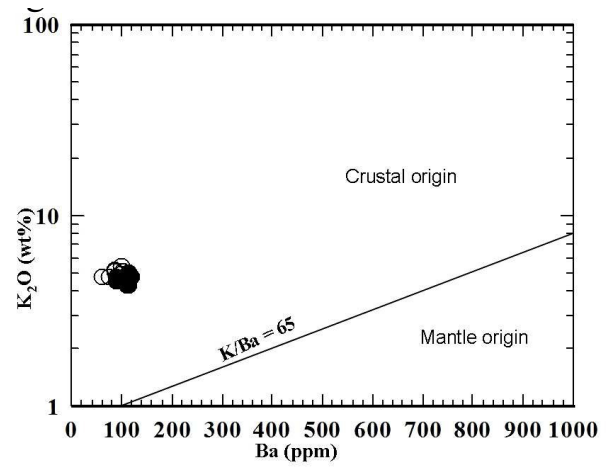

Fig. 21: $\mathrm{K}_{2} \mathrm{O}$ vs. Ba diagram according to Mason (1966) showing the crustal materials sources of both monzogranite and pegmatites rocks 
$\mathrm{Rb} / \mathrm{Sr}$ ratio $(>1.5)$ indicates pre-existing felsic material in the source rock region, but low $\mathrm{Rb} / \mathrm{Sr}$ ratio $(<0.7)$ suggests derivation from the upper mantle. In the studied monzogranites and pegmatites, the $\mathrm{Rb} / \mathrm{Sr}$ ratios of monzogranite range from 2.0 to 4.12 and from 2.0 to 3.3 in pegmatites (Tables $1 \& 2$ ). $\mathrm{Rb} / \mathrm{Sr}$ ratio rise up to 2.0 suggest the presence of felsic materials in their source and were derived from sialic crust or indicate crustal contamination; also exhibiting the moderate role of fractional crystallization of the studied rocks.

Concerning the $\mathrm{Ba} / \mathrm{Rb}$ ratio of both the studied monzogranites and associated pegmatites it lies around 0.5 being far below the crustal ratio of Mason (1966), suggesting the contribution of sialic crustal material.

\section{RADIOACTIVITY}

Eighteen samples (10 from monzogranites and 8 from pegmatite bodies) in Dahab area have been analyzed for radio elements determination (Table 3). Equivalent uranium content of the studied monzogranites ranges from $6 \mathrm{ppm}$ to $11 \mathrm{ppm}$ with an average of 7.5 ppm, which is slightly higher than the average of granitic rocks ( $\mathrm{U}=4 \mathrm{ppm})$ of Rogers and Adams (1969). However, the Equivalent uranium content of the studied pegmatites varies from $7 \mathrm{ppm}$ to $411 \mathrm{ppm}$ with an average of $(88.6 \mathrm{ppm})$ being much higher than the average of granitic rocks (Rogers and Adams, Op.Cit).

On the other hand, the Equivalent thorium content of the studied monzogranite varies from $13 \mathrm{ppm}$ to $26 \mathrm{ppm}$ and averaging 19.5 $\mathrm{ppm}$, which is slightly greater than the average of granitic rocks (Th, $19 \mathrm{ppm}$ ) of Rogers and Adams (Op.Cit). While the Equivalent thorium content of the pegmatites is also variable and ranges from $18 \mathrm{ppm}$ to $390 \mathrm{ppm}$ and the mean value is several times higher than the average of pegmatite rocks. $\mathrm{K}$ contents are generally higher in pegmatites than monzogranites.
Table 3: Radiometric measurements of studied monzogranites and pegmatites

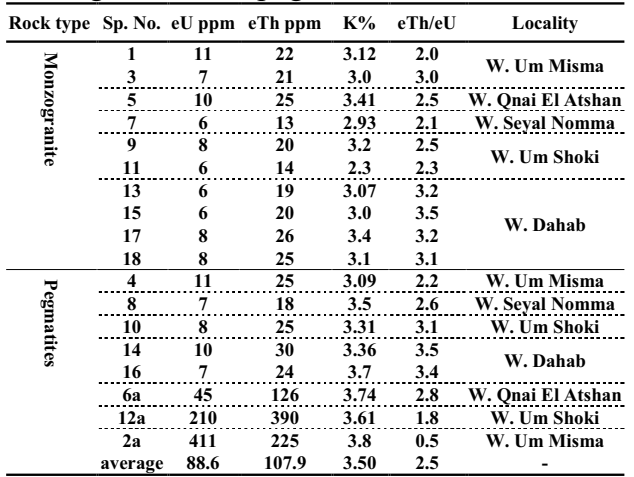

It has been found experimentally that uranium and thorium have a good geochemical coherence during crystallization of a granitic magma (Rogers and Adams, 1969; Mathews, 1978). As a result of a given magma the Th/ $\mathrm{U}$ ratio is fairly constant and thorium and uranium are highly correlated (Nash, 1979; Stuckless, 1979; Ali et al., 2005 and Raslan et al., 2010). A binary diagram of Shaw (1968) showing thorium and uranium contents of the studied monzogranites and associated pegmatites is illustrated on (Fig.22-24). It is clear from this diagram that there is a strong positive correlation between uranium and thorium which could be related to the differentiation trends Fig (22). In Figurss 25 and 26, the variation of eU and eTh versus $\mathrm{K} \%$ indicates that in the anomalous pegmatites in radioactive elements follows the pegmatitic trend while for the monzogranites and the barren pegmatites, they exhibit the magmatic trend.

In contrast to uranium, thorium has a single insoluble tetravalent state being geochemically associated with uranium (Adams and Weaver, 1958), and therefore is useful standard for comparison purposes (Macfarlane et al., 1989; Doventon and Prensky, 1992). So the eTh/eU ratio has proved to be useful in the recognition of geochemical facies (Anjos et al., 2005). The eTh/eU ratios $<1$ are highly suggestive of relative uranium enrichment and implicates reducing conditions as contrasted with ratios $>7$ indicating preferential removal of uranium, 


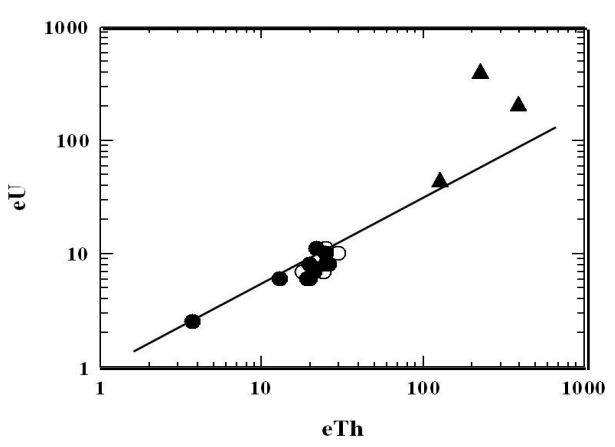

Fig.22: Binary diagram after Shaw, 1968 showing the relationship eU vs.eTh, monzogranites $(\bullet)$, pegmatite $(\circ)$ anomalous pegmatites $(\boldsymbol{\Delta})$

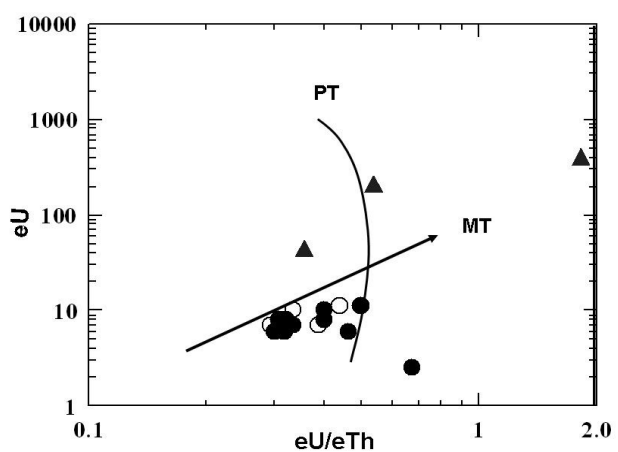

Fig. 23: Binary diagram after Shaw, 1968 showing the relationship eU vs. eU/eTh, Symbols as in Fig. 22

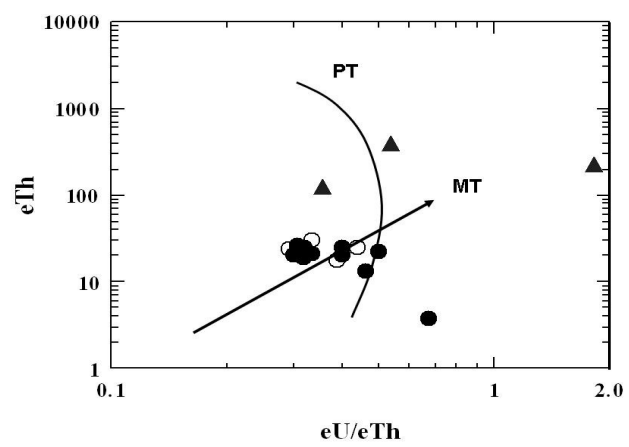

Fig.24: Binary diagram after Shaw, 1968 showing the relationship eTh vs eU/eTh, Symbols as in Fig. 22

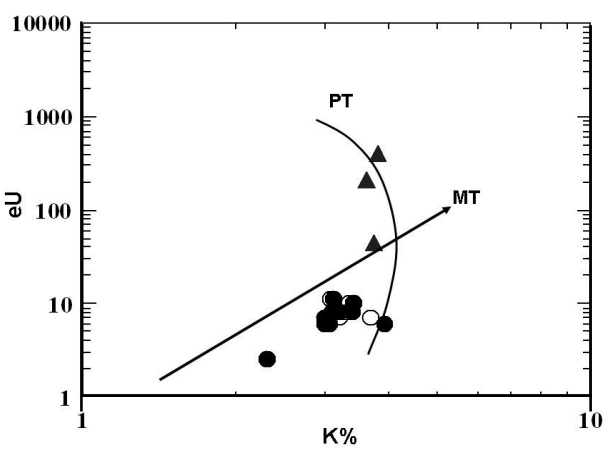

Fig.25: Binary diagram after Shaw, 1968 showing the relationship eU vs. K\%, Symbols as in Fig. 22

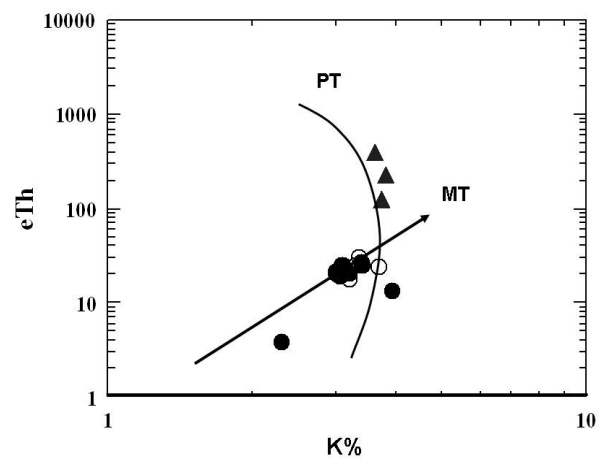

Fig.26: Binary diagram after Shaw, 1968 showing the relationship eTh vs. K\%. MT (magmatic trends) and PT (pegmatite trends). Symbols as in Fig.22

possibly by leaching. It is clear from Table (3) that the eTh/eU ratio of the studied granites and pegmatites ranges between 2.1 and 3.5. This indicates that the studied granites and pegmatites have not be enriched or depleted in uranium. The low ratio in the anomalous pegmatites ranges between $0.5-2.0$ indicates strong hydrothermal addition of uranium in these rocks.

\section{Mineralization and Radioactive Anomalies}

The radiometric investigation in the study area recorded the presence of three radioactive anomalies in pegmatitic bodies: 


\section{The First occurrence}

It is present at Wadi Qnai El Atshan (location 6a - Fig.1). It is found as a pocket of unzoned pegmatite body ( $1 \times 3 \mathrm{~m}$ in dimensions $)$. This high radioactivity is mainly attributed to the presence of zircon and columbite.

Zircon ( $\mathrm{ZrSiO}$ ) occurs as subhedral to euhedral crystals, mainly colorless to blackish yellow in color. The EDAX analyses of zircon crystals indicate the presence of $\mathrm{Zr}, \mathrm{Si}$, $\mathrm{Hf}$ and significant amount of Th and U (Fig.27).

Columbite I(Fe,Mn) $\left.(\mathrm{Nb}, \mathrm{Ta})_{2} \mathrm{O}_{6}\right]$. The columbite-tantalite series are the most abundant minerals in the granitic pegmatites associated with albite, microcline, lepidolite, and muscovite. It was recorded in many localities in the world. EDAX analyses of columbite indicate that it is distinctly enriched in $\mathrm{U}$ contents resulting from the presence of submicroscopic uranium inclusions in this mineral and its metamict state, but depleted in Mn and REEs (Fig. 28).

\section{The Second occurrence}

It was recorded at Wadi Um Shoki (location12a- Fig. 1) in an unzoned pegmatite body $(5 \mathrm{~m} \times 20 \mathrm{~m}$ in dimensions $)$. The radioactive measurements increase along the strike of the fault plane (N200E - S200W) cutting this body. The high radioactivity is attributed to the presence of thorite and uranothorite. Several authors reported the presence of thorite inclusions in rare metal mineralization and accessory heavy minerals separated from some Egyptian pegmatites (Ali et al., 2005; Abdel Warith et al., 2007; Raslan et al., $2010 \mathrm{a \& b).}$

Thorite (ThSiO), occurs as anhedral, fine to very fine black opaque crystals separated from Um Shoki pegmatitic body. It was identified by scanning electron microscope, the obtained EDAX spectrum for thorite reflects the chemical composition of thorite. These results indicate that the major elements in thorite are Th and Si. Also, minor amounts of Fe, $\mathrm{Ca}, \mathrm{Al}, \mathrm{Mg}$, and $\mathrm{Ti}$ are reported as substitution in thorite (Fig. 29).

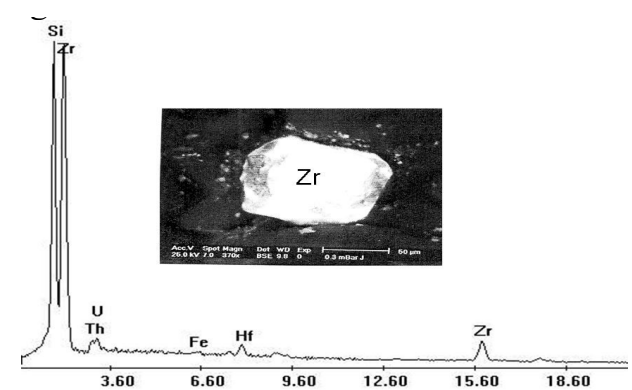

Fig.27: EDX and back scattered images of zircon of Wadi Qinai El Atshan anomalous pegmatite

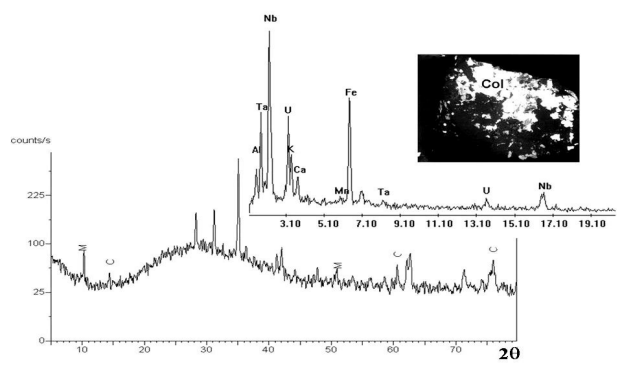

Fig. 28: columbite (EDX \& XRD) of Wadi Qnai El Atshan anomalous pegmatite

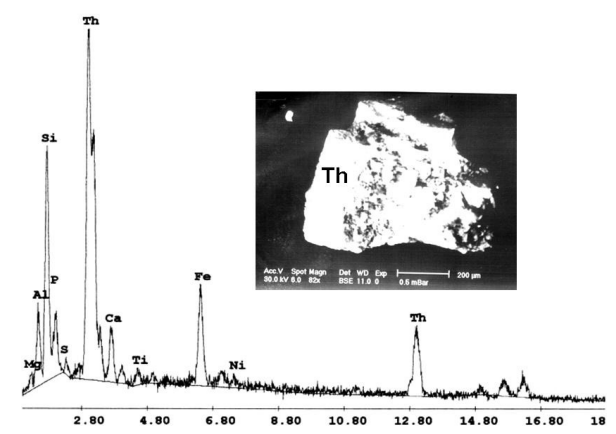

Fig. 29: thorite of Wadi Um Shoki anomalous pegmatite

Uranothorite (U,Th)SiO $)$ is found as fine opaque inclusions. It was separated by bromoform, and identified by scanning electron microscope. The EDAX analyses of uranothorite reflect that the major elements are $\mathrm{Th}, \mathrm{U}$ and $\mathrm{Si}$. Minor amounts of $\mathrm{Fe}, \mathrm{Al}, \mathrm{Ca}, \mathrm{Pb}$ and $\mathrm{Mg}$ were reported as substitution in uranothorite (Fig. 30). 


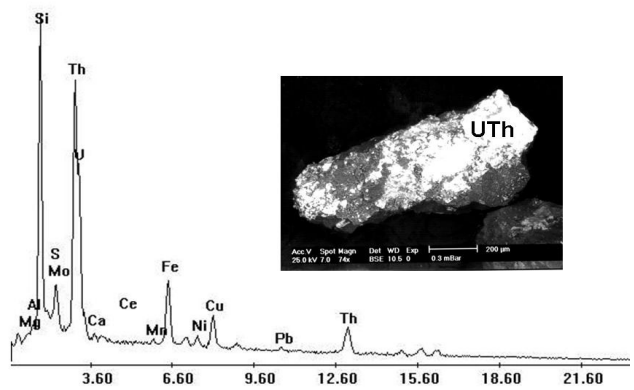

Fig.30 :uranothorite of Wadi Um Shoki anomalous pegmatite

\section{The Third occurrence}

It is recorded at Wadi Um Misma (location 2a- Fig. 1) in a zoned pegmatite body $(2 \times 4 \mathrm{~m}$ in dimensions). The anomaly is also increasing along the fault plane striking N200E - S200W. The high radioactivity is attributed to the presence of autunite and monazite.

Autunite $\left[\mathrm{Ca}\left(\mathrm{UO}_{2}\right)_{2}\left(\mathrm{PO}_{4}\right)_{2}, 8-12 \mathrm{H}_{2} \mathrm{O}\right], \quad \mathrm{Ca}$ uranyl phosphate mineral. This secondary uranium mineral results from the oxidation of primary uranium in hydrothermal veins, granites and pegmatites. This mineral is fairly common in oxidation zones of most uranium deposits (Cesbron et al., 1993). In the studied zoned pegmatite of Wadi Um Misma; the autunite crystals are generally characterized by their dull luster and present as soft aggregates of bright yellow color, sometimes, coated with iron oxides of red color; associated with amorphous silica forming very soft grains. The EDAX analyses data (Fig. 31) confirms the chemical composition of autunite. The major elements are $\mathrm{U}, \mathrm{Ca}$ and $\mathrm{P}$, together with minor amounts of $\mathrm{Fe}, \mathrm{Si}, \mathrm{Bi}$ and $\mathrm{Al}$.

Monazite [(Ce,La, Y,Th) $(\mathrm{PO})]$ a phosphate mineral essentially of $\mathrm{Ce}$ and Th. It is widely disseminated as an accessory mineral in granitic and gneissic metamorphic rocks, detrital sands; also, occurs as relatively large crystals in pegmatites (Deer et al., 1992). Th is usually present in substitution for (Ce, La). The amount of Th present ordinarily ranges from a few weight percent of $\mathrm{ThO}_{2}$ to 10 or

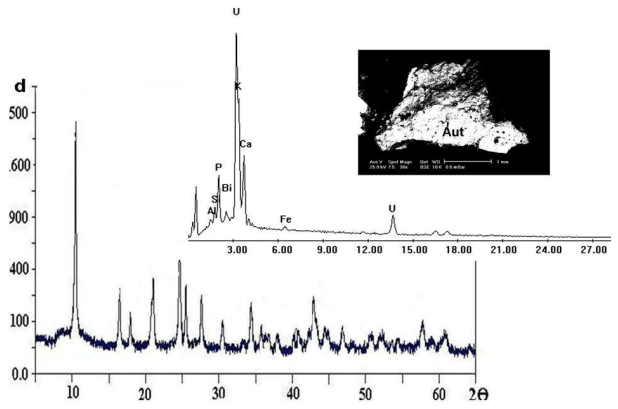

Fig. 31: Autunite (EDX \& XRD) of Wadi Um Misma anomalous pegmatite

$12 \%$. Y substitutes in small amount for $(\mathrm{Ce}$, La) together with minor amounts of $\mathrm{Ca}$ and less abundantly, $\mathrm{Mg}, \mathrm{Fe}^{\prime \prime}, \mathrm{Fe}^{\prime \prime \prime}$ (perhaps due to oxidation), $\mathrm{Al}, \mathrm{Zr}, \mathrm{Be}$, and $\mathrm{Sm}$. Si is often reported in amounts up to several percent of $\mathrm{SiO}_{2}$. The $\mathrm{Si}$ has been ascribed to alteration or to admixed thorite but may in part be due to substitution of Si for P, (Dana, 1963). U is generally present in amount up to $\sim 1$ weight percent of $\mathrm{U}_{3} \mathrm{O}_{8}$. Concentrations of $\mathrm{UO}_{2}$ in granitic monazites rarely exceed $1 \%$. (Cuney and Friedrich, 1987). On the other hand, granitic pegmatites are usually characterized by monazites of higher $U$ concentrations e.g., 9.5 $\mathrm{wt} \% \mathrm{UO}_{2}$ (Gulson and Krogh, 1973) and 15.6 $\mathrm{wt} \% \mathrm{UO}_{2}$ (Gramaccioli and Segalstad, 1978).

The composition of this mineral in the studied anomalous pegmatite at Wadi Um Misma is determined by using the ESEM as on (Fig. 32). The EDAX spectrum for this

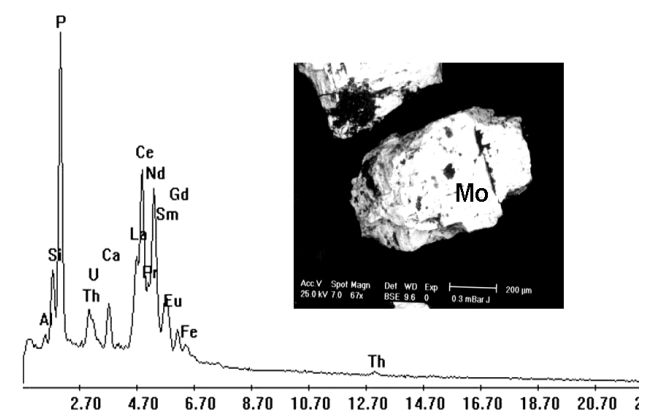

Fig. 32: monazite of Wadi Um Misma anomalous pegmatite 
mineral reflects the chemical composition of monazite (Fig. 32). The analysed monazite contains $\mathrm{La}, \mathrm{Ce}$ and $\mathrm{Nd}$. The $\mathrm{Ce}: \mathrm{Nd}$ ratio $=3: 2$ indicates that the mineral can be considered a monazite (Ce). Certain minerals such as monazite, bastnaesite and allanite are Ce- selective and prefer the LREE. Thus the Ce- group or LREE tend to be concentrated in highly fractionated acid rocks such as alkaline granites and pegmatites.

\section{SUMMARY AND CONCLUSIONS}

Field, petrographic, mineralogical and geochemical investigations of younger granites and pegmatites indicate the similarity of their petrographical and geochemical characters reflecting their genetic relationship and lead to the concept that the studied pegmatites were formed through progressive liquid and crystal melt fractionation following monzogranites during the final stage of magma crystallization.

Geochemically, the monzogranites and hosted pegmatites have high $\mathrm{K}$-calc alkaline characters, metaluminous and peralkaline natures, intruded in within-plate environment, derived from magma of crustal materials source of moderate fractionation.

The monzogranites and pegmatites are almost having uranium contents more than twice Clarke value (Clarke value $=4 \mathrm{ppm}$, Clarke et al., 1966) so they can be consider as uraniferous rocks. Some of these pegmatite bodies have abnormal radioactivity. Radionuclide measurements of monzogranites show that their equivalent uranium content $(\mathrm{eU})$ ranges between $6 \mathrm{ppm}$ and $11 \mathrm{ppm}$, while their equivalent thorium (eTh) varies from 13 ppm to $26 \mathrm{ppm}$. The average contents of $\mathrm{U}$ and $\mathrm{Th}$ of the anomalous pegmatites are 88.6 ppm and $107.9 \mathrm{ppm}$, respectively indicating their uraniferous nature. The high radioactivity in the pegmatite bodies is attributed to the presence of, thorite, uranothorite, autunite, zircon, monazite and columbite.

The Mineralogical investigations of anomalous pegmatites revealed the presence of secondary uranium mineral (autunite), in addition to thorite, uranothorite, zircon, monazite and columbite. Primary and secondary radioactive mineralizations indicated that the mineralization is not only magmatic, but also post-magmatic.

\section{REFERENCES}

Abdel Warith, A., Raslan, M.F. and Ali, M.A., 2007. Mineralogy and radioactivity of pegmatite bodies from the granitic pluton of Gabal Um Tager El-Tahtani area, Central Eastern Desert, Egypt. 10th Inter. Mining, Petrol. and Metall. Engin. Conf., Fac. Engin., Cairo Univ.

Abu El Liel, I., Hassan, M. M., Abdel Tawab, M. M., and Abdel Rahman, H. B., 1990. Geological and geochemical studies on Feirani Group: The proposed Late Proterozoic younger volcanic rocks, Sinai. Egypt. Miner. 2, 61-80.

Adams, J.A.S., Weaver, C.E.,1958. Thorium to uranium ratios as indications of sedimentary processes: example of concept of geochemical facies. Amer. Assoc. Petrol. Geol. Bull., 42, 387-430.

Ali, M. A., Raslan, M. F., and El-Feky, M. G.,2005. Radioactivity and mineralogy of some pegmatite bodies from Gabal AlFarayid granites, South Eastern Desert, Egypt. 9th Inter. Min. Petrol. Metall. Engin. Conf., Fac. Engin., Cairo Univ.

Anjos, R.M., Veiga, R., Soares, T., Santos, A., Aguiar, J., Frascac, M., Brage, J., Uzeda, D., Mangia, L., Facure, A., Mosquera, B., Carvalho, C., and Gomes, P.,2005. Natural radionuclide distribution in Brazilian commercial granites. J. Radiat.Meas. 39, 245-253.

Beyth, M., Grunhagen, H., and Siberfrab, A.,1975. An ultramafic rock in the Precambrian of Eastern Sinai, Geol. Mag. $115,373-378$. 
Bowden, P.,1985). The geochemistry and mineralization of alkaline ring complex in Africa- (a review). J. Afri. Earth Sci., 3, $17-39$.

Bucanan, M. S.,1982. The geochemistry of some igneous rocks. Geochem cosmochem. Acta, 9, 297-308.

Cesborn, F., Idefonse, P., and Sichere, M. D.,1993. New mineralogical data on uranophane and B-uranophane:synthesis of uranophane. Geol. Magazine, 57, 301308.

Clarke, M. B.,1981. The mineralogy of peraluminous granites, a review. Can. Contrib.Miner. Petrol., 79, 3-17.

Clarke, S. P. Jc., Peterman, Z. E., and Herer, K. S.,1966. Abundances of uranium, thorium and potassium. In: Clarke, S. P. (ed.), Handbook of physical constant. Geol. Soc. Am. Met. 97, Soc. 24, $521-541$.

Collins, W. J., Beams, S. D, White, A. J. R., and Chappell, B. W.,1985. Nature and origin of A-type granites with particular reference to southeastern Australia. Contr. Miner. Petrl. 80, 189 - 200.

Cox, K.C., Bell, J.D., and Pankhurst, R.J., 1979. The interpretation of igneous rocks. William Clowes, London, Britain, 414 p.

Cuney, M., and Friedrich, M.,1987. Physicochemical and crystal-chemical controls on accessory mineral paragenesis in granitoids: Implications for uranium metallogenesis. Bulletin Mineralogie, 110, 235247.

Dana, E.S.,1963. A textbook of mineralogy. John Wiley and Sons. Inc., New York and London, 851p.

Deer, W. A., Howie, R. A., and Zussman, J.,1992. An introduction to the-rock forming minerals. ELBS, Longman, 528p.

De La Roche, H., Leterrier, J., Grandelaude, P., and Marcheal, M.,1980. A classifica- tion of volcanic and plutonic rocks using R1-R2 diagram and major elements analyses: Its relationships with current nomenclature. Chem. Geol. 29, $183-210$.

Doventon, J.H., Prensky, S.E., 1992. Geological applications of wireline logs: a synopsis of developments and trends. Log Anal. 33 (3), 286-303.

Eby, N.G.,1990. The A-type granitoids: a review of their occurrence and chemical characteristics and speculations on their petrogenesis. Lithos, 26, 115-134.

El Aassy, I. E., Shazly, A. G., Hussien, H. A., Heikel, M. T., and El Gaby, M. M.,1997. Pegmatites of Nuwiba-Dahab area, west Gulf of Aqaba, Sinai, Egypt, Field aspects, mineralogy, geochemistry and radioactivity. 3rd Intern. Conf. Geochem. Fac. Sci. Alex. Univ. Egypt, 13p.

El Badawi, M. A.,1988. Geology and geochemistry of the basement rocks of Dahab area, Sinai, Egypt. M. Sc. Thesis, Cairo Univ.

El Masry, N. N. L.,1989. Geology of extrusive and intrusive rocks of Feirani area, southern Sinai, Egypt. Ph. D. Thesis, Suez Canal Univ., Ismaillia, Egypt, 164p.

El Sayed, A. A.,1993. Geology and radioactivity of west Dahab area, southeastern Sinai, Egypt. M Sc. Thesis, Mansoura. Univ., 174p.

El Shazly, E. M., Dixon, T. H., Engle, A. E. J., Abdel Maguide, A. A., and Stern, R. J.,1980. Late Precambrian crustal evolution of Afro-Arabian from ocean - arc to craton, Egypt. J. Geol. 24, $101-121$.

El Reedy, M. W.,1984. The general, physical and chemical features and the pollution level of El Sabahia-Sabhan-El Requa soil localities, State of Kuwait. Report represented to environmental protection Dept., Ministry of Public Health, Kuwait (Part I: chemical methods). 
Eyal, M., Eyal, Y., Bartove, Y., and Stenitz, G.,1989. The tectonic development of the western margin of the Gulf of Elat (Aqaba) rift. Tectonophysics, $80,39-66$.

Gramaccioli, C. M., and Segalstad, T. V.,1978. A uranium- and thorium-rich monazite from a south-alpine pegmatite at Piona, Italy. Amer. Mineral., 63, 757-761.

Gulson, B. L., and Krogh, T. E.,1973. Old lead component in the young Bergell Massif, south-east Swiss Alps. Contributions to Mineralogy and Petrology, 40, 239-252.

Harker, A.,1909. Natural history of ignous rocks, Macmillan. NewYork, 339P.

Harris, N. B. W.,1985. The petrogenesis of alkaline intrusion from Arabian and northeast Africa and their implications for within- plate magmatism. Tectonophysics 83, $243-258$.

Itamar, A.,1989. Precambrian felsic volcanism in the Arabian area, southeastern Sinai. Isr. Geol. Surv., 83 - 44.

Katta, L. A. S.,1989. Geological, mineralogical and geochemical studies on the plutonic rocks east Wadi Saal area, southern Sinai, Egypt. Ph.D. Thesis. Mansoura. Univ., 174p.

Khalaf, E. A.,2002. Petrogenesis of Feirani volcanics, southwestern Sinai, Egypt. Egypt J. Geol., 46 - 183.

Macfarlane, P.A., Whittemore, D.O., Townsend, M.A., Doventon, J.H., Hamilton, V.J., Coyle III, W.G., Wade, A., Macpherson, G.L. and Black, R.D.,1989. The Dakota Aquifer Program Annual Report, FY89. Appendix B. Kansas Geological Survey, Open-File Rept., 90-27.

Mason, B.,1966. Principles of geochemistry 3 rd edition. John Wiley \& Sons, New York, 239p.

Mathews, G. W.,1978. Uranium occurrences in and related to igneous rocks .U.S. Dept.
Energy Open- File GJBX-67(78), 121180.

Nash, J.T.,1979. Uranium and thorium in granitic rocks of north-eastern Washington and northern Idaho, with comments on uranium resource potential. U.S. Geol. Surv., Open- File Rept. 79-233, 39 p.

Nardi, L. V. S., and Bonin, B.,1991. Post-orogenic and non-orogenic alkaline granite association, The Saibro intrusive suite, southern Brazil,A case study. Chem. Geol. 92,197- 211.

Pearce, J. A., Harris, N. B. W., and Tindle, A. G.,1984. Trace element discrimination diagrams for the tectonic interpretation of granitic rocks. J. Petrol. 25, 956 -9 83.

Peccerillo, R., and Taylor, S. R.,1976. Geochemistry of Eocene calc-alkaline volcanic rocks from the Kastamonu area Northern Turkey. Cont. Miner. Petrol.,81, $58-63$.

Raslan, M.F., El-Shall, H.E., Omar, S.A., and Daher, A.M.,2010a. Mineralogy of polymetallic mineralized pegmatite of Ras Baroud granite, Central Eastern Desert, Egypt. J. Mineral. Petrol. Sci., 105, 123-134.

Raslan, M.F., Ali, M.A., and El feky, M.G.,2010b. Mineralogy and radioactivity of pegmatites from South Wadi Khuda area, Eastern Desert, Egypt. Chinese J. Geochem., 29, 343-354.

Rogers, J.J.W., and Adams, J.S.S.,1969. Uranium. In: Wedepohl. K.H. (ed.), Handbook of geochemistry. New York, Springer-Verlag. 4, B1-92.C10, 92 p.

Shand S. I.,1950. Eruptive rocks. J. Wiley, New York, 4th edition.

Shapiro, I., and Brannock, W. W.,1962. Rapid analysis of silicate, carbonate and phosphate rocks. U. S. Geol. Surv. Bull. 1144A, $65 \mathrm{p}$. 
Shaw, D. M.,1968. A review of K-Rb fractionation trends by covariance analyses. Geochim. Cosmochim. Acta, 32, 573600.

Stern, R. J., and Hedge, C. E.,1985. Geochronological and isotopic constrains on late Precambrian crustal evolution in the Eastern Desert of Egypt. Am. J. Sci. 285, $97-127$.
Streckeisen, A.,1976. To each plutonic rock its proper name. Earth Sci. Rev., 12,1-33.

Stuckless, J. S.,1979. Uranium and thorium concentrations in Precambrian granites as indicators of a uranium province in central Wyoming. Contrib. Geol. (Wyo.Univ.) 17, 173 -178.

Taylor, S. R., and McLennan, S. M.,1985. The continental crust: Its composition and evolution, Oxford, England, Blackwell, 312p.

$$
\begin{aligned}
& \text { علاقة الإشعاعية والمنشأ بين صخور الجرانيت المونزونيتى والأجسام البجماتيتية التي تحتويها }
\end{aligned}
$$

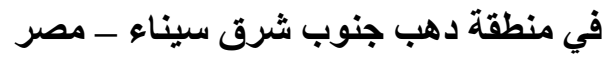

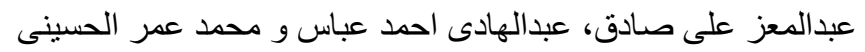

$$
\begin{aligned}
& \text { تقع منطقة الدراسة في الجزء الجنوب الثرقي من شبه جزيرة سيناء على امتداد الجانب الغربي من خليج }
\end{aligned}
$$

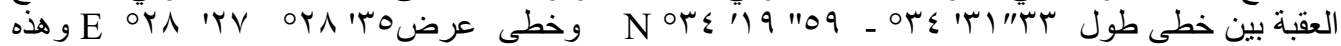

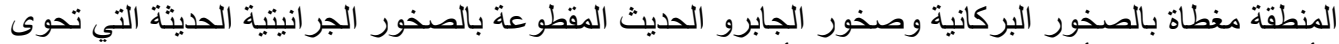

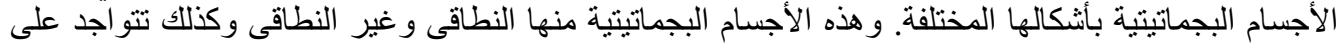

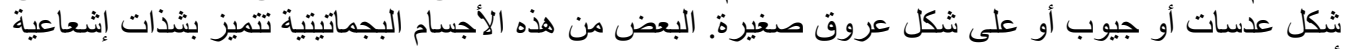

$$
\begin{aligned}
& \text { أعلى من الجر انيتات المتداخلة فيها. }
\end{aligned}
$$

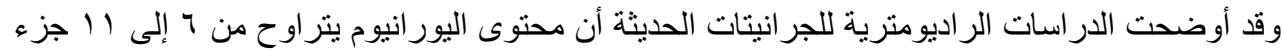

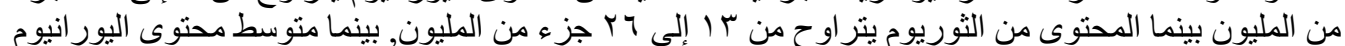

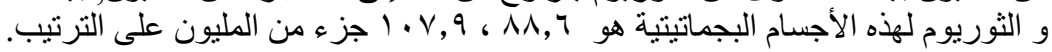

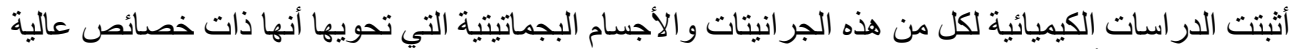

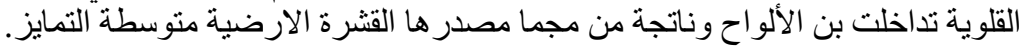

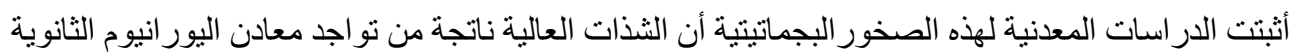

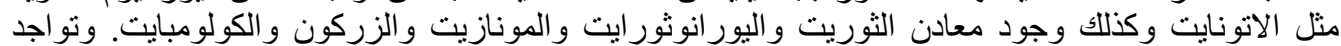

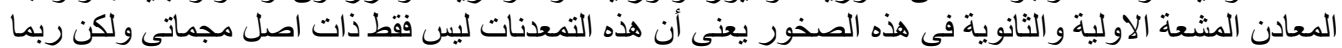

$$
\begin{aligned}
& \text { تأثرت بالعمليات النلاحقة. }
\end{aligned}
$$

